\title{
INTERVALO HÍDRICO ÓTIMO DE UM LATOSSOLO VERMELHO EM FUNÇÃO DO CONTROLE DE TRÁFEGO AGRÍCOLA SOB CULTIVO DE CANA-DE-AÇUCAR
}

\author{
Gustavo Cassarotti (IC), Guilherme Castioni (PG), Zigomar Souza (PQ) \\ Resumo
}

O objetivo desse estudo foi avaliar três configurações de plantio com controle de tráfego, buscando identificar a melhor resposta da planta correlacionando com o intervalo hídrico do solo em área de cana-deaçúcar. Foram coletadas amostras de solo indeformadas na linha da cultura, nas camadas de 0,00-0,10 m, $0,10-0,20 \mathrm{~m}$ e $0,20-0,30 \mathrm{~m}$ para determinação do IHO. O intervalo hídrico ótimo do solo foi sensível às alterações promovidas pelos sistemas de manejo agrícola, indicando seus valores críticos de densidade, porosidade e resistência do solo à penetração.

Palavras Chave: redução do espaçamento, limites críticos, compactação do solo.

\section{Introdução}

O intervalo hídrico ótimo (IHO) é um atributo do solo sensível aos efeitos da compactação do solo, sendo sugerido como indicador de qualidade física do solo que influencia diretamente na produção das culturas (TORMENA et al., 1998; BLAINSKI et al., 20089). O IHO do solo engloba informações sobre resistência do solo à penetração, disponibilidade de água e aeração do solo (SILVA et al., 1994; ROQUE et al., 2011), indicando assim o conteúdo de água onde as limitações são mínimas ao desenvolvimento das culturas.

O presente trabalho teve por objetivo desenvolver - modelo de intervalo hídrico ótimo de um Latossolo Vermelho sobre três configurações de plantio com controle de tráfego, buscando identificar a melhor resposta da planta correlacionando com o intervalo hídrico do solo em área de cana-de-açúcar.

\section{Resultados e Discussão}

O limite inferior do $\mathrm{IHO}$ foi explicado pela resistência do solo à penetração que exerceu uma ligeira restrição, observado o modelo de $\mathrm{IHO}$ do solo em questão (Figura 1). Podendo ser explicado pelo aumento da densidade do solo, levando em consideração que nas condições em que há 0 aumento da densidade concomitantemente ocorre à redução da porosidade (ROQUE et al., 2011).

Conhecido o $\mathrm{IHO}$ do solo, então encontra-se a densidade em que o IHO é igual a zero, chamada de densidade crítica para que a planta tenha seu desenvolvimento pleno. Os valores da densidade crítica variam de 0,97 a $1,54 \mathrm{Mg} \mathrm{m}^{-3}$, indicativo de que houve um incremento na densidade do solo por conta do tráfego de máquinas.

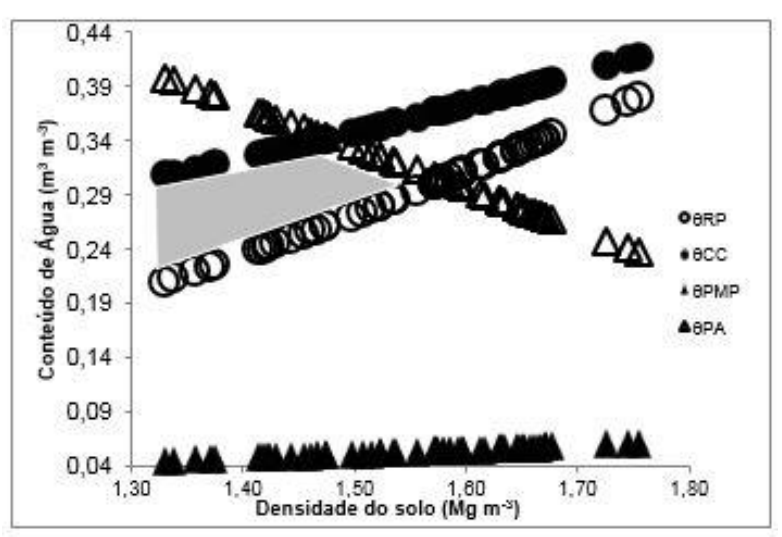

Figura 1. Conteúdo de água em função da densidade do solo, dos limites críticos da capacidade de campo (CC), do ponto de murcha permanente (PMP), da porosidade de aeração de $0,10 \mathrm{~m}^{3} \mathrm{~m}^{-3}(\mathrm{~A})$ e da resistência do solo à penetração (RP).

\section{Conclusões}

O intervalo hídrico ótimo do solo foi sensível às alterações promovidas pelos sistemas de manejo agrícola, indicando seus valores críticos de densidade e porosidade e resistência do solo à penetração.

\section{Agradecimentos}

Os autores agradecem a Fundação de amparo a pesquisa do estado de São Paulo (FAPESP) pelo financiamento do projeto.

\footnotetext{
${ }^{1}$ Blainski, E.; Tormena, C. A.; Fidalski, J.; Guimarães, R. M. L. Quantificação da degradação física do solo por meio da curva de resistência do solo à penetração. R Bras Ci Solo, 2008, 32, 975-983. ${ }^{2}$ Roque, A. A. O.; Souza, Z. M.; Araújo, F. S.; Silva. G. R. V. Atributos físicos do solo e intervalo hídrico do solo de um Latossolo Vermelho distrófico sob controle de tráfego agrícola. Ci Rural, Santa Maria, v.41, n.9, p.1536-1542, 2011.

${ }^{3}$ Silva, A. P.; Kay, B. D.; Perfect, E. Characterization of the least limiting water range. Soil Sci Soci Ame Jour, v.58, p.1775-1781, 1994.

${ }^{4}$ Tormena, C. A.; Silva, A. P.; Libardi, P. Caracterização do intervalo hídrico ótimo de um Latossolo Roxo sob plantio direto. R Bras Ci Sol, 1998, v.22, 73-581.
} 